\title{
The Toxic Effect Of Sildenafil Citrate On Adult Albino Rat Testis And The Possible Protective Role Of Royal Jelly (Histological And
} Original Immunohistochemical Study)

Article

\author{
Hanan I. El-Kerdasy, Ali Mohamed Ali Mohamed
}

Department of Anatomy and Embryology, Faculty of Medicine, Benha University, Egypt

\begin{abstract}
Background: Phosphodiesterase inhibitor was appearing as a magic tool in treatment of erectile dysfunction, however, it might lead to harmful effects in high dose and long term administration.

The aim of the work: This study aimed to evaluate the toxic effect of sildenafil citrate on the histological structure of the testis of adult albino ratsand the possible protective role of royal jelly.

Materials and methods: Thirty five adult male albino rats were divided into 3 groups; the control group divided into (subgroup $\mathrm{Ca}, \mathrm{Cb}$ and $\mathrm{Cc}$ ), experimental group divided into (subgroup $\mathrm{Ea}$ and $\mathrm{Eb}$ ) and treated group divided into (subgroup $\mathrm{Ta}$ and $\mathrm{Tb}$ ). In the experimental group sildenafil citrate was given at a dose of $9 \mathrm{mg} / \mathrm{kg}$ in subgroup Ea and $13.5 \mathrm{mg} / \mathrm{kg}$ in subgroup Eb orally daily for 30 days. In the treated group rats were treated by royal jelly at a dose of $100 \mathrm{mg} / \mathrm{kg}$ for $30 \mathrm{days}$ orally after stoppage of sildenafil citrate. In the present study, the sperm count, histological and immunohistochemical studies were evaluated.

Result : Daily oral administration of sildenafil citrate $(9 \mathrm{mg} / \mathrm{kg}$ and $13.5 \mathrm{mg} / \mathrm{kg})$ for 30 day had reduced the sperm count and induced apparent degeneration with detached, distorted germ cell and congested blood vessels with significant decrease in Proliferating cell nuclear antigen Labeling Index (PCNA- LI). After royal jelly administration, there was an improvement in sperm count and histopathological changes induced by sildenafil citrate with a significant increase in PCNA -LI.

Conclusion: Long-term daily use of Sildenafil citrate produced histological changes in the testis and reduced the spermatogenesis with a significant decrease in sperm count and these side effects can be prevented by using royal jelly.
\end{abstract}

Received: 14 October 2018, Accepted: 14 January 2019

Key Words: PCNA-LI, royal jelly, sildenafil citrate, testes.

Corresponding Author: Hanan I. El-Kerdasy, MD, Anatomy and Embryology Department, Faculty of Medicine, Benha University, Benha, Egypt, Tel.: +20 1007618122, E-mail: mhanan909@yahoo.com

ISSN: $1110-0559$, Vol. 42, No. 2

\section{INTRODUCTION}

Erectile dysfunction (ED) is the inability to get a sufficient erection; it affects one in each ten men. ED results from vascular or neurogenic abnormalities, psychogenic, drug induced and hormonal disorders ${ }^{[1]}$.

Sildenafil was synthesized at first for treatment of hypertension and angina pectoris but it was approved to induce marked penile erection.

The drug has been found to be effective in men with mild to moderate ED without any organic cause ${ }^{[2]}$.

Sildenafil protects cyclic guanosine monophosphate (cGMP) from degradation by cGMP-specific phosphodiesterase type 5 (PDE5) in the corpus cavernosum. The increased levels of cGMP leads to smooth muscle relaxation, vasodilation and increased inflow of blood into the spongy tissue of the penis, causing erection ${ }^{[3]}$.

The molecular structure of sildenafil is similar to that of cGMP and acts as a competitive binding agent of PDE5 in the corpus cavernosum, resulting in more cGMP and better erections ${ }^{[4]}$.
Previous studies had concluded that Sildenafil induced tubular and interstitial histological alterations of the seminiferous tubules and tubular degeneration, which finally might lead to an arrest of spermatogenesis ${ }^{[5]}$.

Royal jelly is secreted from the glands in the heads of worker bees and is fed to all bee larvae ${ }^{[6]}$. Royal jelly is composed of $67 \%$ water, $12.5 \%$ protein, and $11 \%$ simple sugars and (5\%) fatty acids. The main acid is the 10-hydroxy-2-decenoic acid (10-HDA). It also contains many trace minerals, some enzymes, antibacterial and antibiotic components, pantothenic acid (vitamin $\mathrm{B}_{5}$ ), pyridoxine (vitamin B6) and trace amounts of vitamin $\mathrm{C}^{[7]}$.

Royal jelly has been used in medicine as antimicrobial, antitumor, antihypertensive, and as an immune regulator ${ }^{[8]}$. Many researches on royal jelly has been done and found that royal jelly improves male fertility as it has a protective effect on sperm count, sperm motility, viability, maturity and testosterone levels in mice ${ }^{[9]}$.

This research aimed to evaluate the toxic effect of sildenafil citrate on adult albino rat testis and the possible protective role of royal jelly. 


\section{MATERIALS AND METHODS}

\section{Animals}

In the present study, thirty five adult male albino rats obtained from the animal house, Moshtohor Faculty of Veterinary Medicine, Benha University; were used with an average weight of $(200-250 \mathrm{~g})$. Rats were housed individually in clean cages of well aerated environment, given a normal daily diet and maintained at 12/12 hour light/dark cycle. All the ethical protocols for animal treatment were followed and supervised by the animal house facility.

\section{Drugs}

Sildenafil citrate was obtained as $100 \mathrm{mg}$ tablet produced by Pfizer, Egypt (Viagra). The tablets were crushed and dissolved in distilled water for oral administration. The dose was selected equivalent to the daily dose for treating ED, The dose was calculated according to Paget and Barnes $^{[10]}$, where the human daily dose was multiplied by the rat conversion factor (0.018), and then the result multiplied by 5 to calculate the dose/ $\mathrm{Kg}$ of rat

Humans dose $\mathrm{x} 0.018=\mathrm{X} \mathrm{mg} / 200 \mathrm{~g}$ of rat.

$\mathrm{X} m \mathrm{~m} \times 5=\mathrm{Ymg} / \mathrm{kg}$.

In this study we used $9 \mathrm{mg} / \mathrm{kg}$ of rat equivalent to 100 mg per day for adult human dose a high dose of sildenafil citrate $^{[11]}$ and $13.5 \mathrm{mg} / \mathrm{kg}$ of rat equivalent to $150 \mathrm{mg}$ per day for adult human dose an over dose of sildenafil citrate $^{[12]}$.

Royal jelly was obtained as $1000 \mathrm{mg}$ tablet soft gelatin capsules produced by pharco pharmaceuticals, Alexandria, Egypt. The capsules were dissolved in corn oil for oral administration. Rats were administered $100 \mathrm{mg} / \mathrm{kg}$ royal jelly ${ }^{[13]}$.

\section{Experimental design}

Thirty five adult male albino rats were divided into three groups as follow:

Control group: Fifteen rats were divided into 3 subgroups:

Subgroup Ca: It included five rats. They received only distilled water daily for 30 days.

Subgroup Cb: It included five rats which received 100 $\mathrm{mg} / \mathrm{kg}$ royal jelly daily for 30 days orally.

Subgroup Cc: It included five rats. They received only corn oil daily for 30 days orally.

Experimental group: Ten rats were divided into 2 subgroups:

Subgroup Ea: It included five rats which received $9 \mathrm{mg} /$ $\mathrm{kg}$ sildenafil citrate dissolved in distilled water daily for 30 days, through orogastric feeding tube (equivalent to 100 mg adult human dose).

Subgroup Eb:- It included five rats which received 13.5 $\mathrm{mg} / \mathrm{kg}$ sildenafil citrate dissolved in distilled water daily for 30 days, through orogastric feeding tube (equivalent to $150 \mathrm{mg}$ adult human dose).

Treated group: Ten rats were divided in to 2 subgroups:

Subgroup Ta:-It included five rats which received 9 $\mathrm{mg} / \mathrm{kg}$ sildenafil citrate orally daily for 30 days, then the rats were given $100 \mathrm{mg} / \mathrm{kg}$ royal jelly daily for another 30 days orally after stoppage of Sildenafil citrate.

Subgroup Tb:- It included five rats which received 13.5 $\mathrm{mg} / \mathrm{kg}$ sildenafil citrate orally daily for 30 days, then the rats were given $100 \mathrm{mg} / \mathrm{kg}$ royal jelly daily for another 30 days orally after stoppage of Sildenafil citrate.

At the end of experiment, all rats were living. They were anaesthetized with inhalation of diethyl ether. Midline chest incision was performed, incision was taken on the scrotum of each rat, the testis and epididymis were carefully exposed and removed and then the sperms collected from the epididymis. The testis was fixed in $10 \%$ neutral buffered formalin. After fixation, specimens had been processed for paraffin embedding. The testis had been sectioned at a thickness of 5-7 microns for histological staining.

\section{1-Sperm count}

The epididymis along with a part of the vas deference was carefully separated from the testes. The cauda was then gently dissected with a scalpel blade to allow sperms to emerge from the cauda epididymis which was then dipped into a plastic petri dish $(35 \mathrm{~mm})$ containing pre warmed incubation medium (saline). Sperms released into the medium and were incubated for approximately $3 \mathrm{~min}$ and then the collected samples were diluted with water in a ratio 1: 20 in order to dilute them. 10 micron of it was taken by micropipette and put on hemocytometer slide for counting the sperms under $\times 400$ magnifications ${ }^{[14]}$ by light microscope. Under the microscope, sperms heads were counted in the 5 large squares, and then multiply that value by 5 to obtain the number of sperms per a central counting area. The average number of sperms was multiplied by 10.000 to obtain the number of sperm per $\mathrm{ml}$ of diluted sample. The number of sperms per $\mathrm{ml}$ in the original sample was obtained by multiplying the previous count in the dilution factor

The following equation was used to get the concentration of the original sperm sample in the term of numbers $/ \mathrm{ml}$.

Concentration $/ \mathrm{ml}=$ (dilution factor) (count in 5 squares) $\left(0.05 \times 10^{6}\right)^{[15]}$.

\section{2-Histopathological Examination}

Examination of the testis tissue sections, stained by Hematoxylin and Eosin (H\&E) was carried out to evaluate the histological architectural changes in the testis tissues.

\section{3-Immunohistochemical Examination}

Proliferating cell nuclear antigen (PCNA) is an 
intranuclear polypeptide that is involved in DNA replication, repair and excision. Its expression and synthesis is linked to cell proliferation ${ }^{[16]}$. Since spermatogenesisis a complex cell cycle of rapidly proliferating cells ending with liberation of sperms, PCNA was used in this study to quantitatively analyze spermatogenesis. Immunohistochemical staining was carried out using primary antiserum to PCNA (Clone PC 10, DAKO A/S Denmark). The primary antibody was diluted in Trisbufferd saline with a dilution of 1:50, as determined by the data sheet. The sections were incubated with the primary antibody overnight at $+4^{\circ} \mathrm{C}$. Enough Biotinylated secondary antibodies were applied to cover specimen then the binding of the primary antibody was observed using a commercial avidinbiotin-peroxidase detection system recommended by the manufacturer (DAKO, Carpenteria, USA). A mouse monoclonal antibody was applied in place of the primary antibody to act as a negative control. Sections from the small intestine were used as a positive control. Then the slides were stained with diaminobenzene (DAB) as the chromogen and counter stained with hematoxylin then slide dehydrated in $95 \%$ ethanol, cleared in xylene then cover slips were mounted using two drop of DPX mounting medium ${ }^{[17]}$.

\section{PCNA-Labeling Index (PCNA-LI) ${ }^{[18]}$}

Slides were examined under the light microscope with a magnification of $X 200$, and then sections were examined for PCNA immunostaining. Microscopic fields were chosen randomly. Five fields per slide and five slides per animal were evaluated. Only the basal germ cells of these seminiferous tubules were counted, because they are the cells where active DNA synthesis took place. The PCNA-LI for each somniferous tubule was estimated as a percentage of immuno-labeled cells to all basal cells. For each specimen, the mean $+\mathrm{SD}$ was calculated, then, the total PCNA-LI for all groups was estimated accordingly.

\section{Statistical Analysis}

Statistical analysis of the obtained data was performed using ANOVA test. Pvalues $<0.05$ were considered significant.

\section{RESULTS}

\section{Sperm count}

In control group the results revealed that the sperm count was significantly higher $(p<0.05)$ in $\mathrm{Cb}$ subgroup which received $100 \mathrm{mg} / \mathrm{kg}$ royal jelly daily for 30 days orally as compared to the sperm count in $\mathrm{Ca}$ and $\mathrm{Cc}$ subgroups. The effect of long term administration of sildenafil citrate (9 $\mathrm{mg}$ and $13.5 \mathrm{mg}$ ) in adult male rats caused a significant reduction in sperm count as compared to that of control group. In the experimental group the results revealed that the sperm count was significantly lower $(p<0.05)$ in subgroup $\mathrm{Eb}$ as compared to the sperm count in subgroup $\mathrm{Ea}$, this result was a dose dependent, higher dose of sildenafil causes more reduction in the sperm count. In the treated group the results revealed that the sperm count was significantly higher $(p<0.05)$ after administration of royal jelly as compared to the sperm count in the experimental group (Table 1).

\section{Histological Results}

\section{Control group}

Histological examination of testicular sections from the control subgroups were comparable and showed that the seminiferous tubules appeared with regular outlines and were lined by layers of germinal epithelium at different stages of spermatogenesis. The lining epithelium consisted of germinal cells and sertoli cells. The germinal epithelium consisted of spermatogonia cells lying on a basement membrane, large rounded 1ry spermatocytes and spermatids recognized by their darkly stained rounded nuclei and its position towards the lumen, while spermatozoa appeared elongated in shape with pointed end. The flagella of mature sperms were seen filling the lumens of the seminiferous tubules. The interstitial spaces in between the tubules contained Leydig cells. Histological profile of testis in subgroup $\mathrm{Cb}$ that received $100 \mathrm{mg} / \mathrm{kg}$ royal jelly daily for 30 days orally as compared to that of $\mathrm{Ca}$ and $\mathrm{Cc}$ subgroups (Figure 1).

\section{Experimental group}

Histological examination of the testicular sections from subgroup (Ea) revealed that the testicular tissues were partially affected. Affected seminiferous tubules appeared with irregular outlines surrounded by apparent thin basement membrane and showed disorganized germinal epithelium with detached distorted shrunken germ cells with pale nuclei. There were empty spaces in between germ cells and decrease sperm flagella in the lumens of seminiferous tubules. There were congested blood vessels between the tubules (Figure 2). In subgroup $(\mathrm{Eb})$ the testicular tissues were totally affected in which most of seminiferous tubules appeared depleted of most of spermatogenic cells as there were large empty spaces in between germ cells that appeared detached and shrunken with pyknotic nuclei. The basement membrane was thin and irregular with few sperm flagella in the lumens of tubules (Figure 3).

\section{Treated group}

Histological examination of the testicular sections from subgroup ( $\mathrm{Ta}$ ) revealed a total improvement in which seminiferous tubules with their germinal epithelium appeared to be comparable to those of the control group with increase sperm flagella in the lumens of seminiferous tubules as compared to that of subgroup (Ea) (Figure 4). While subgroup (Tb) revealed a partial improvement in which some seminiferous tubules appeared with intact germinal epithelium and sperm flagella in their lumens as compared to that of subgroup (Eb). However, there were some seminiferous tubules showing germ cells with pale nuclei and few sperm flagella (Figure 5). 


\section{Immunohistological results}

Immunohistological examination of the testicular tissues had detected spermatogenic cells labeled in the sections. It included spermatogonia and primary spermatocytes. The control group revealed positive immunostaining (brown nuclear reaction) in most of the germ cells in the seminiferous tubules. The experimental group revealed few immune positive germ cells in the seminiferous tubules in subgroup (Ea) and less in the subgroup (Eb). The treated group revealed some immune positive germ cells in the seminiferous tubules of the subgroup (Ta) which were more than in subgroup (Tb) (Figures. 6,7,8,9 and 10 ).
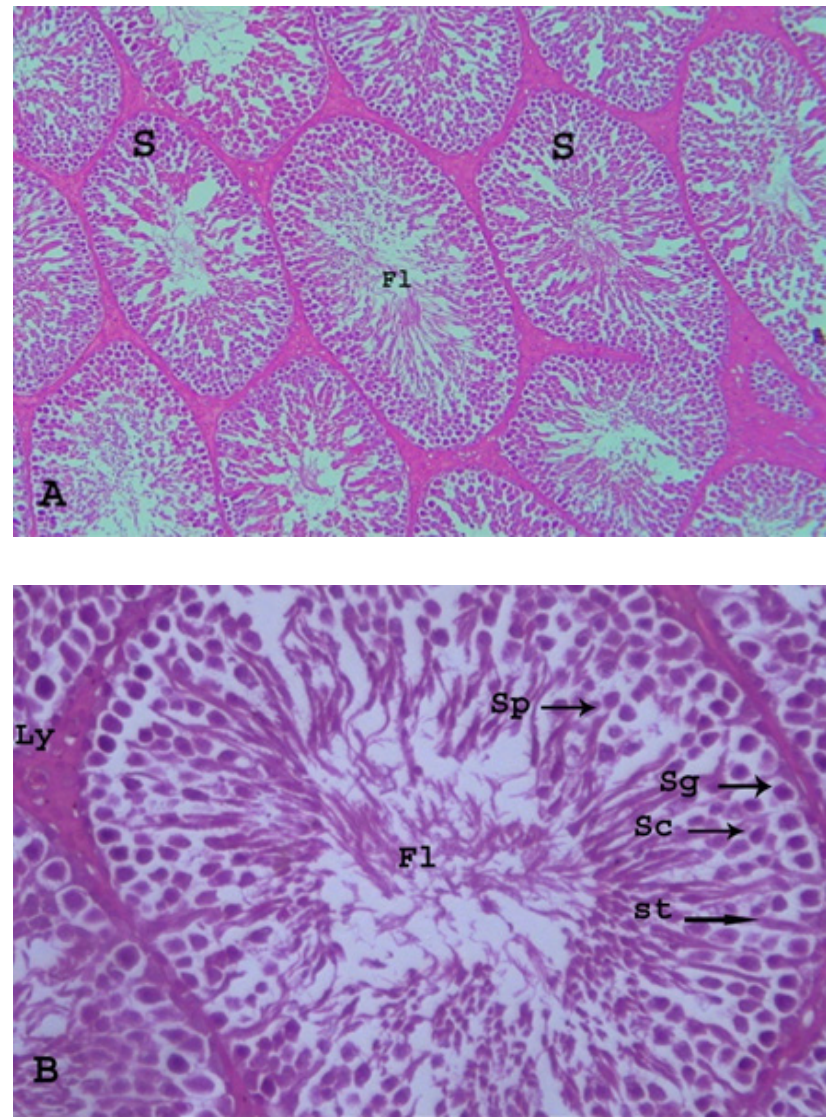

\section{PCNA-LI Results}

In control group the PCNA-LI value revealed that subgroup $\mathrm{Cb}$ had a value $85 \pm 1.4$ which was higher than the values of subgroups $(\mathrm{Ca}$ and $\mathrm{Cc})$ that were $(78.6 \pm 1.3$ and $76 \pm 9.2$ respectively). In experimental group the PCNA-LI value revealed that the values were significantly lower in subgroups $\mathrm{Ea}$ and $\mathrm{Eb}(31.4 \pm 1.4$ and $14.3 \pm 0.7$ respectively) than those of the control subgroups. In the treated group the PCNA-LI value revealed that the values were significantly higher in subgroup $\mathrm{Ta}$ and $\mathrm{Tb}(63.9 \pm 1.1$ and $51.3 \pm 1.1$ respectively) as compared to that of the experimental subgroups. However, they were still significantly lower as compared to that of the control subgroups (Table 2).
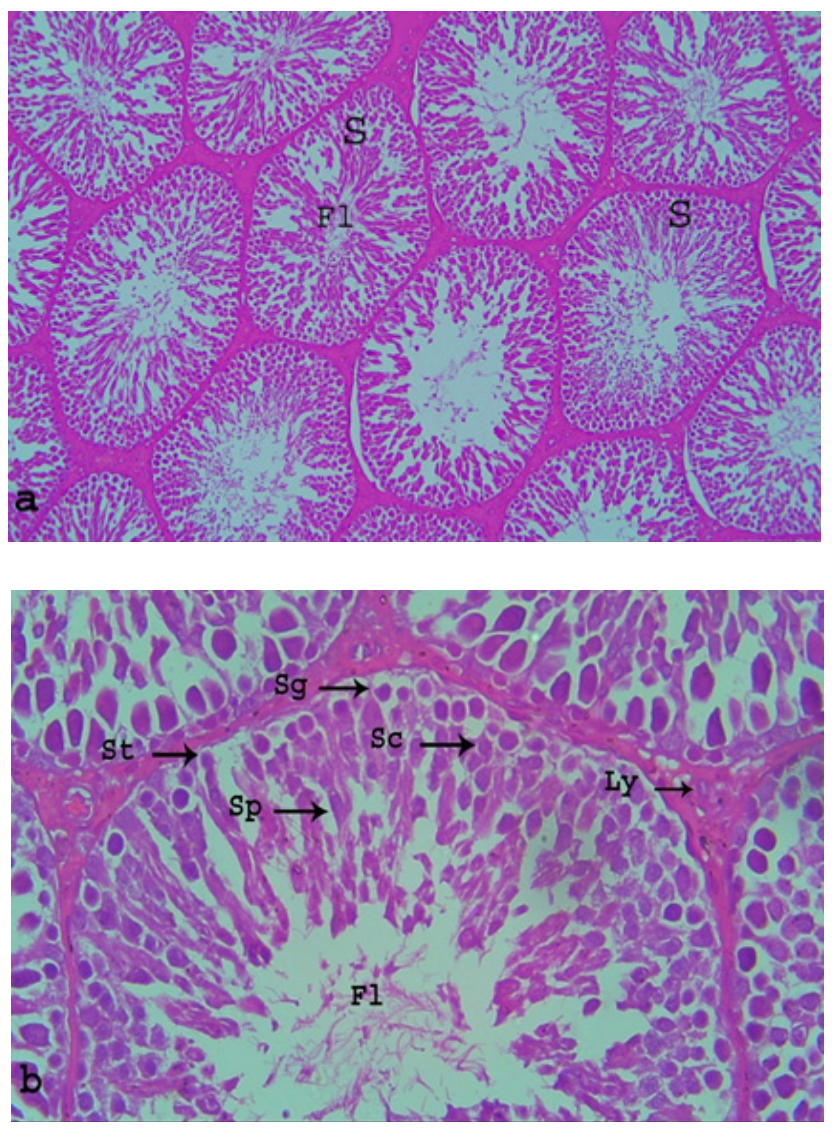

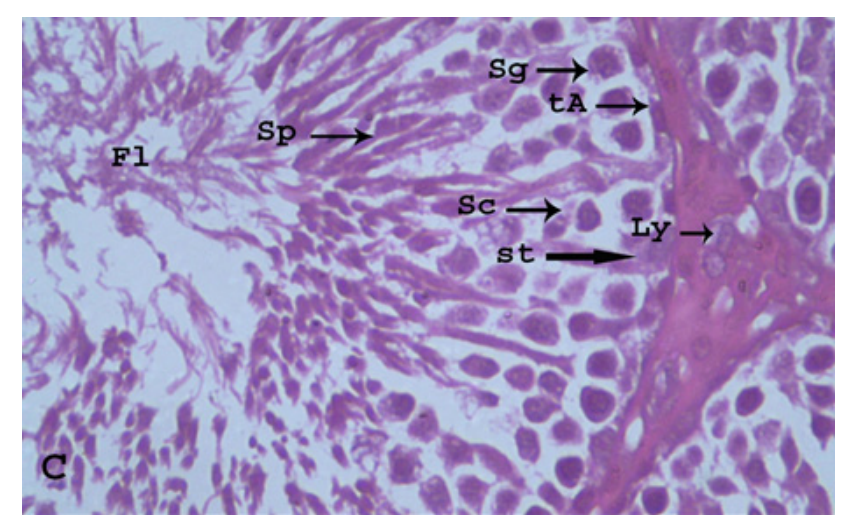

Fig. 1: Photomicrographs of testicular sections of adult male rats in the control group showing A and a. Multiple seminiferous tubules with regular outlines, lined by layers of germinal epithelium (S). The lumen contain sperm flagella (H\&E x100). B and b. Sertoli cells (St), spermatogonia (Sg) spermatocyte (Sc), rounded spermatids $(\mathrm{Sp})$. The flagella of mature sperms are seen in the lumen of the tubules (F1) (H\&E x200).C. Type A spermatogonia (tA) resting on the basement membraine, type B spermatogonia (Sg), spermatocyte (Sc), spermatids (Sp) and leydig cell (Ly) in the interstitial spaces in-between the tubules (H\&E x400). 

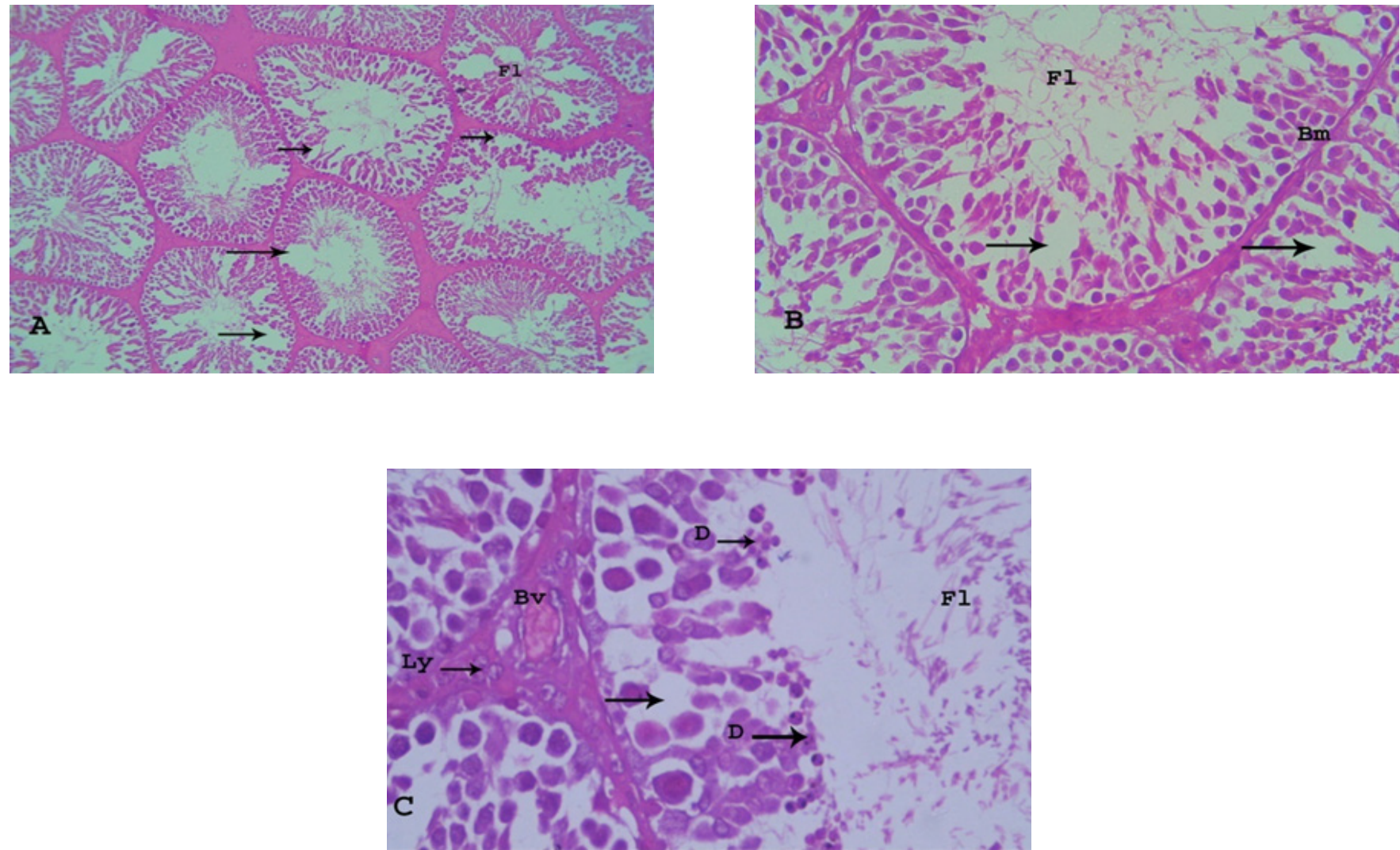

Fig. 2: Photomicrographs of testicular sections of adult male rats in the experimental subgroup (Ea) showing A. Some seminiferous tubules with irregular outlines, empty spaces in between germ cells (arrow), with few flagella of mature sperms in the lumen of the tubules (Fl), (H \& E X100). B. Empty spaces in between germ cells (arrow) and thin basement membrane (Bm) (H \& E X200). C. Most of germ cells are detached distorted shrunken with pale nucleus (D) empty spaces in between germ cells (arrow). The interstitial spaces in-between the tubules contain Leydig cells (Ly) and congested blood vessels (Bv), (H\&E x400).
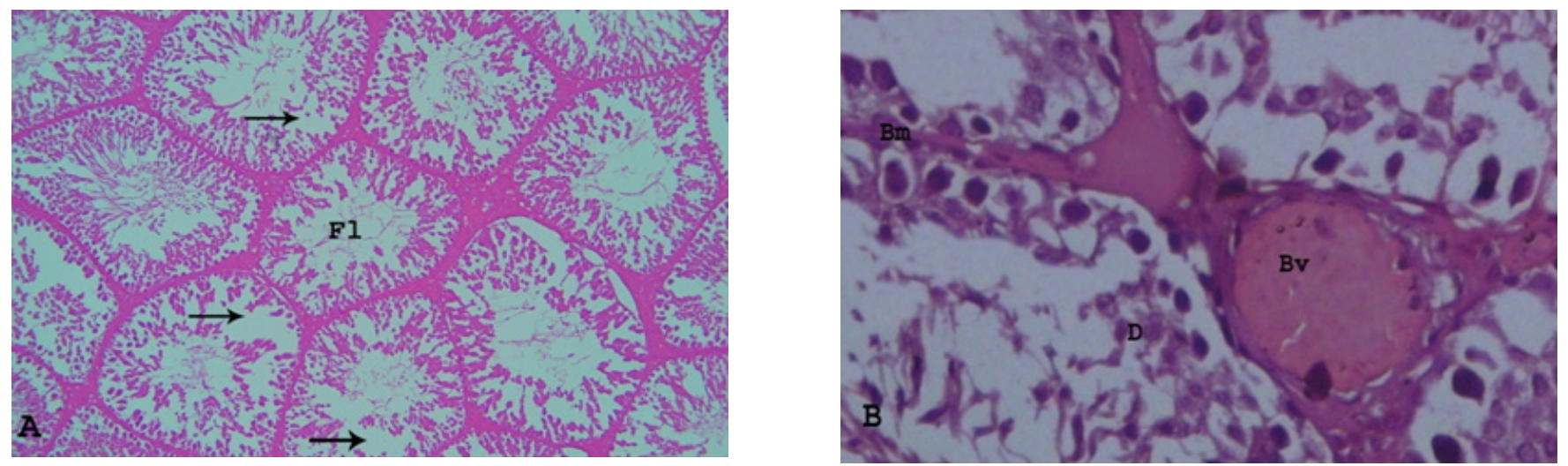

Fig. 3: Photomicrographs of testicular sections of adult male rats in the experimental subgroup (Eb) showing A. almost all seminifrous tubules were depleted of most of spermatogenic cells, there were large empty spaces in between germ cells (arrow), with few sperm flagella in the lumen of some tubules (Fl) (H\&E $\mathrm{x} 100)$. B. all of germ cells are detached and shrunken with pyknotic nuclei (D) with thin basement membrane (Bm). The interstitial spaces in-between the tubules contain congested blood vessels (Bv) (H\&E x200). 

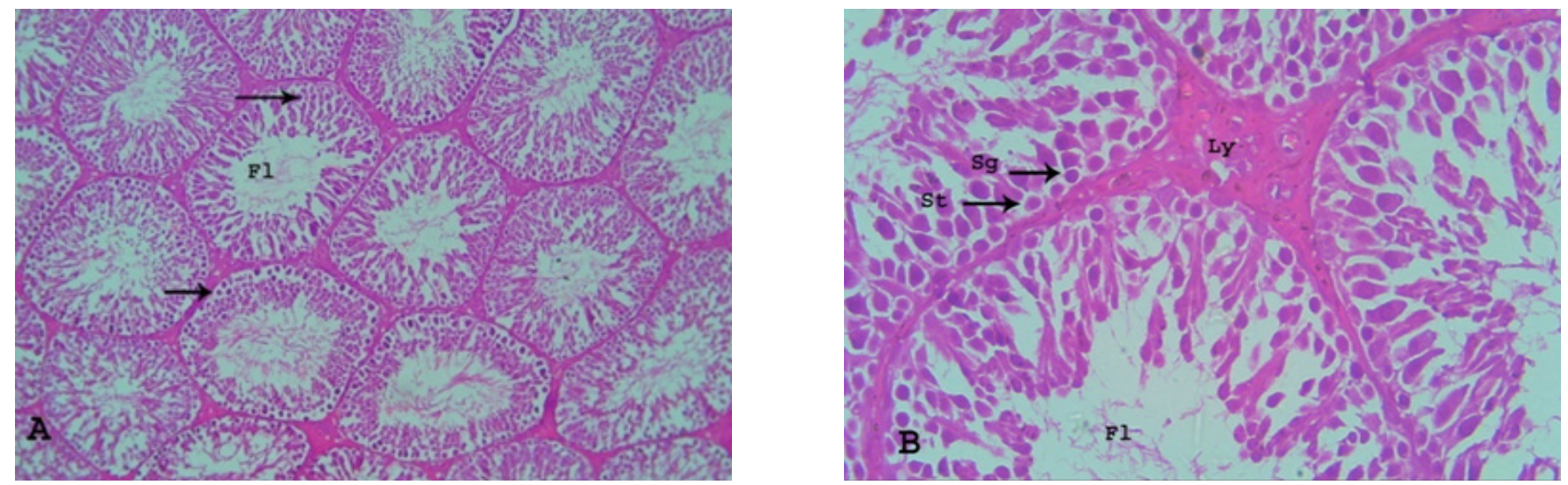

Fig. 4: Photomicrographs of testicular sections of adult male rats in the treated subgroup (Ta) showing A. Most of seminiferous tubules (arrow) with regular outlines with appearance of sperm flagella in the lumen (Fl) (H \&E x100). B. Germ cell appeared nearly normal spermatogonia (Sg), Sertoli cells (St) and Leydig (Ly), (H \&E x200).
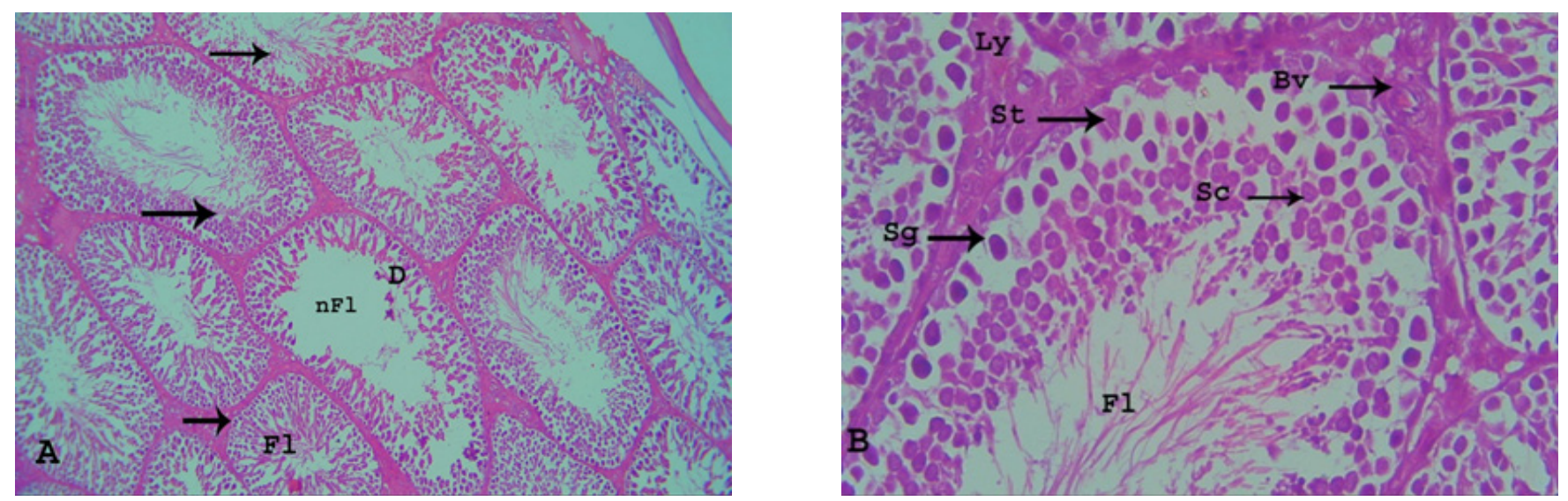

Fig. 5: Photomicrographs of testicular sections of adult male rats in the treated subgroup (Tb) showing A. Some seminiferous tubules (arrow) with sperm flagella (Fl) in the lumen but there are anothers without sperm flagella in their lumen (nFl) and distorted germ cells (D) (H \& E X100). B. spermatogonia (Sg), Sertoli cells (St) with pale nucleus, spermatocyt (Sc) and Leydig (Ly), (H \& E X200).

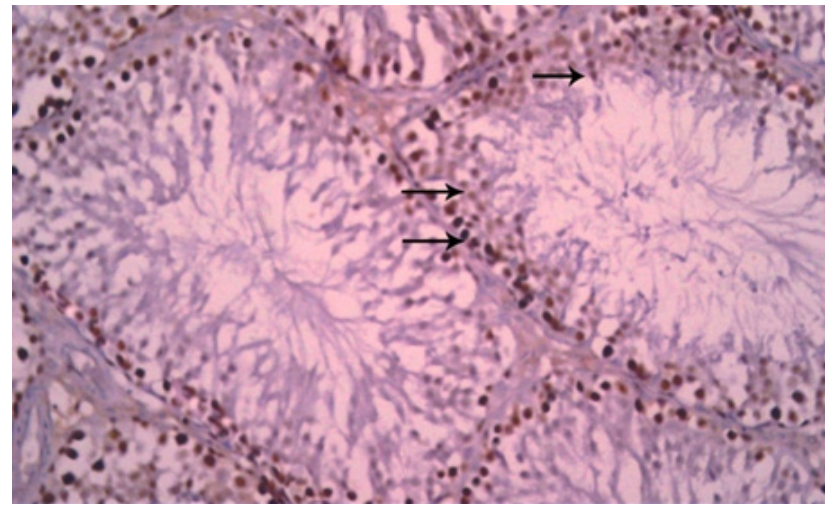

Fig. 6: A photomicrograph of a testicular section of adult male rats from the control subgroup $(\mathrm{Cb})$ showing a positive immunostaining (brown nuclear reaction) in most of the germ cells in the seminefirous tubules (arrows).(PCNA immunohistochemical staining X 200)

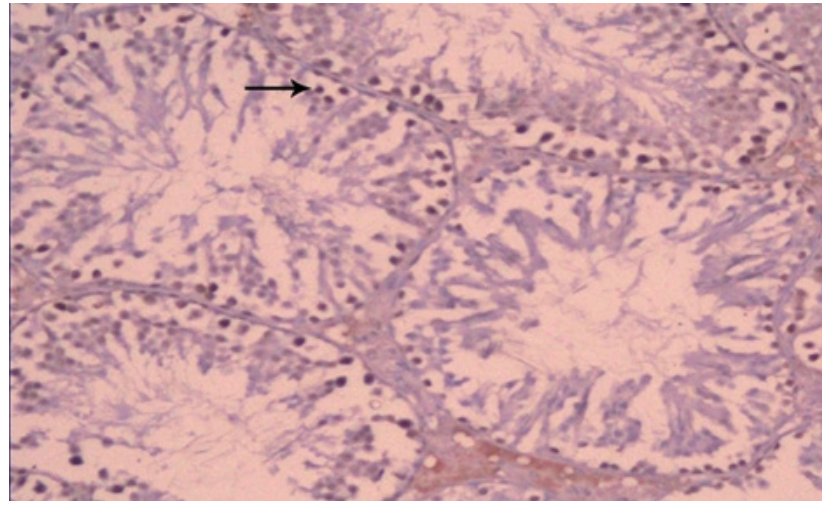

Fig. 7: A photomicrograph of a testicular section of adult male rats from the experimental subgroup (Ea) showing few immunopositive germ cells (arrows). in the seminefirous tubules .(PCNA immunohistochemical staining X 200) 


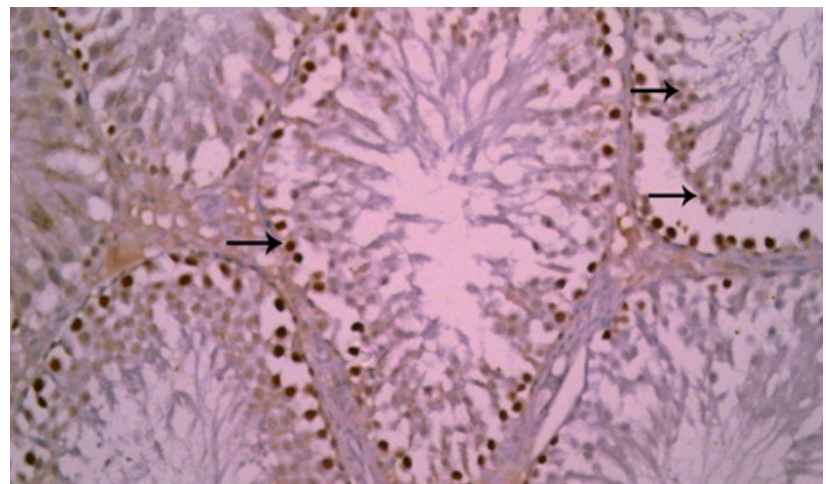

Fig. 8: A photomicrograph of a testicular section of adult male rats from the treated subgroup ( $\mathrm{Ta}$ ) showing many immunopositive germ cells (arrows). in the seminefirous tubules .( PCNA immunohistochemical staining X 200)

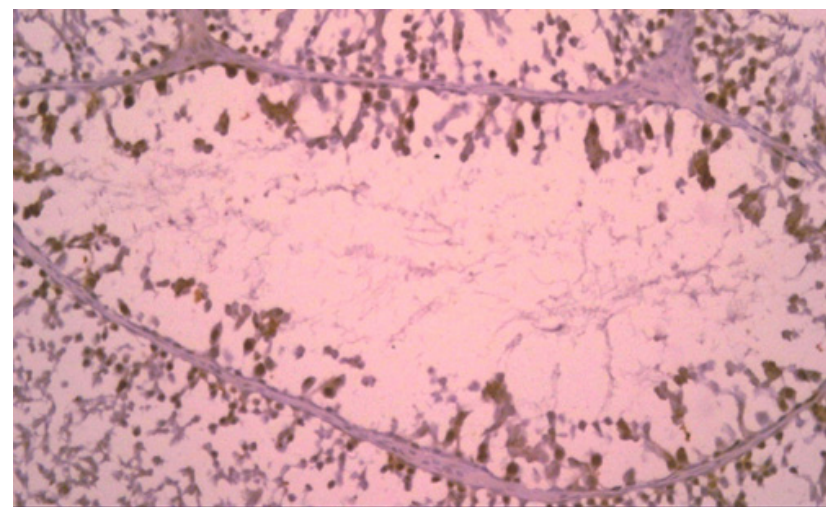

Fig. 9: A photomicrograph of a testicular section of adult male rats from the experimental subgroup (Eb) showing few immunopositive germ cells (arrows). in the seminefirous tubules .(PCNA immunohistochemical staining X 200)

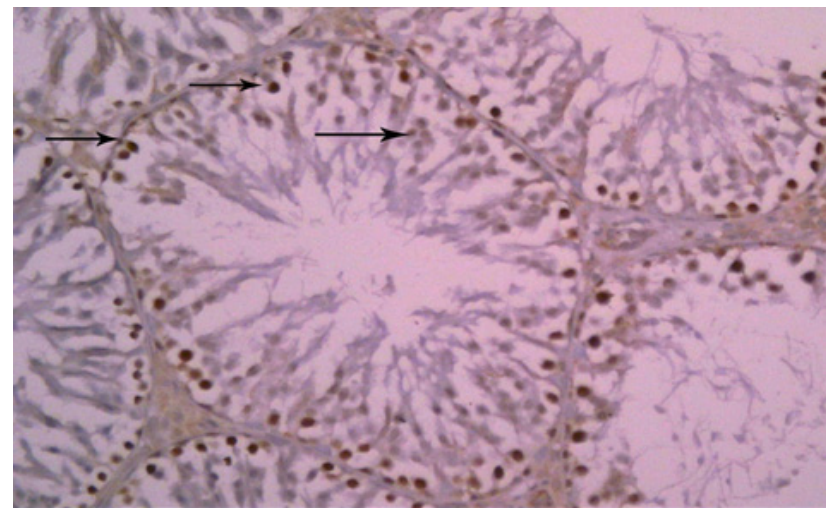

Fig. 10: A photomicrograph of a testicular section of adult male rats from the treated subgroup ( $\mathrm{Tb})$ showing some immunopositive germ cells (arrows). in the seminefirous tubules .( PCNA immunohistochemical staining X 200)
Table 1: Sperm count in control, experimental and treated subgroups

\begin{tabular}{cc}
\hline Subgroup & mean \pm SD \\
\hline Subgroup $(\mathrm{Ca})$ & $181.8 \pm 8.17^{\text {bdefg }}$ \\
Subgroup $(\mathrm{Cb})$ & $210.2 \pm 9.91^{\text {acdefg }}$ \\
Subgroup $(\mathrm{Cc})$ & $179.9 \pm 4.75^{\text {bdefg }}$ \\
Subgroup (Ea) & $89.6 \pm 8.56^{\text {abcefg }}$ \\
Subgroup (Eb) & $40.2 \pm 8.07^{\text {abcdfg }}$ \\
Subgroup (Ta) & $149.8 \pm 12.46^{\text {abcdeg }}$ \\
Subgroup (Tb) & $93.8 \pm 10.57^{\text {abcdef }}$ \\
\hline
\end{tabular}

a: Significant difference $(p<0.05)$ compared with subgroup $(\mathrm{Ca}), \mathrm{b}$ : Significant difference $(p<0.05)$ compared with subgroup $(\mathrm{Cb}), \mathrm{c}$ : Significant difference $(p<0.05)$ compared with subgroup (Cc), d: Significant difference $(p<0.05)$ compared with subgroup (Ea) e: Significant difference $(p<0.05)$ compared with subgroup $(\mathrm{Eb})$, f: Significant difference $(p<0.05)$ compared with subgroup (Ta), g. Significant difference $(p<0.05)$ compared with subgroup $(\mathrm{Tb})$

Table 2: PCNA-LI value in the control, experimental and treated subgroups

\begin{tabular}{cc}
\hline Subgroup & mean \pm SD \\
\hline Subgroup $(\mathrm{Ca})$ & $78.6 \pm 1.3^{\text {cdef }}$ \\
Subgroup $(\mathrm{Cb})$ & $85 \pm 1.4^{\text {cdef }}$ \\
Subgroup $(\mathrm{Cc})$ & $76 \pm 9.2^{\text {defg }}$ \\
Subgroup $(\mathrm{Ea})$ & $31.4 \pm 1.4^{\text {abcefg }}$ \\
Subgroup $(\mathrm{Eb})$ & $14.3 \pm 0.7^{\text {abcdfg }}$ \\
Subgroup $(\mathrm{Ta})$ & $63.9 \pm 1.1^{\text {abcdeg }}$ \\
Subgroup $(\mathrm{Tb})$ & $51.3 \pm 1.1^{\text {abcdef }}$ \\
\hline
\end{tabular}

a: Significant difference $(p<0.05)$ compared with subgroup $(\mathrm{Ca}), \mathrm{b}$ : Significant difference $(p<0.05)$ compared with subgroup $(\mathrm{Cb}), \mathrm{c}$ : Significant difference $(p<0.05)$ compared with subgroup $(\mathrm{Cc})$, d: Significant difference $(p<0.05)$ compared with subgroup (Ea), e: Significant difference $(p<0.05)$ compared with subgroup $(\mathrm{Eb})$, f: Significant difference $(p<0.05)$ compared with subgroup (Ta), g.Significant difference $(p<0.05)$ compared with subgroup $(\mathrm{Tb})$.

\section{DISCUSSION}

The side effects of sildenafil citrate are mostly mild to moderate. But, with higher doses and long term administration of the sildenafil citrate the side effect become severe ${ }^{[19]}$.

This study aimed to investigate the effect of different doses of sildenafil citrate with long term administration on sperm count and testicular tissue of male adult rats and the therapeutic potential protective role of royal jelly.

In the present study the control subgroup $\mathrm{Cb}$ that received $100 \mathrm{mg} / \mathrm{kg}$ royal jelly daily for 30 days orally showed that the sperm count was significantly higher 
$(p<0.05)$ as compared to the sperm count in $\mathrm{Ca}$ and Cc subgroups. This indicated the role of royal jelly in improving the sperm count in normal rats. This was in agreement with ${ }^{[20]}$ they found that the use of royal jelly was very effective for increasing the sperm count and motility.

$\mathrm{Also}^{[21]}$ reported that royal jelly increases sperm count, testosterone hormone level, and the percentage of living sperm. ${ }^{[22]}$ concluded that royal jelly improves rabbits' fertility and physiological status that was reflected in better liver and kidney functions.

In this study long term administration of sildenafil citrate $(9 \mathrm{mg}$ and $13.5 \mathrm{mg}$ ) in adult male rats caused a significant reduction in sperm count as compared to that of control group. In experimental group the results revealed that the sperm count was significantly lower $(p<0.05)$ in subgroup $\mathrm{Eb}$ as compared to the sperm count in $\mathrm{Ea}$ subgroup, this result was a dose dependent, higher dose of sildenafil causes more reduction in the sperm count. This was in agreement with ${ }^{[23]}$ they studied that long term administration of sildenafil was associated with a significant decrease in total sperm count. Also in ${ }^{[24]}$ results showed that prolonged sildenafil citrate exposure lead to decrease in sperm motility, adenosine triphosphate (ATP) content, energy charge, and mitochondrial-generated superoxide. On the other hand, ${ }^{[25]}$ comparing effect of sildenafil with tadalafil in young infertile men they found that there was a significant increase in sperm motility after sildenafil administration but there was a significant decrease in the value after tadalafil. And ${ }^{[26]}$ noticed that $100-\mathrm{mg}$ sildenafil citrate in diabetic patients with or without neuropathy causes increase semen volume and sperm motility.

In this study administration of royal jelly after stoppage of sildenafil citrate revealed that the sperm count was significantly higher $(p<0.05)$ as compared to the sperm count in the experimental subgroups (Ea and $\mathrm{Eb}$ ). This indicated the role of royal jelly in improving the sperm count after testicular injury. Mean while studies on diabetic cases by ${ }^{[13]}$ indicated that royal jelly administration attenuated diabetes-related testicular dysfunction and histopathological changes.

In the present study rat testicular sections from the experimental subgroup (Ea) which received $9 \mathrm{mg} / \mathrm{kg}$ of sildenafil for a long time revealed that the testicular tissues were partially affected. Affected seminiferous tubules appeared with irregular outlines surrounded by apparent thin basement membrane and showed disorganized germinal epithelium with detached distorted shrunken germ cell with pale nuclei. There were empty spaces in between germ cells and decrease sperm flagella in the lumens of tubules. There were congested blood vessels between the tubules. These findings were proved by PCNA-LI value that was significantly lower in subgroup Ea $(31.4 \pm 1.4)$ than those of the control subgroups. ${ }^{[27]}$ Documented that administration of sildenafil caused degeneration of seminiferous tubules with thin basement membrane and the interstitial tissue showed degenerated Leydig cells and congested blood vessels. On the contrary to the present study ${ }^{[28]}$ noticed non-remarkable improvement in testicular and epididymal tissues in normoglycaemic rats after treatment with sildenafil in a dose dependent manner, while there was mild improvement in hyperglycaemic rats.

In this study the rat testicular sections from experimental subgroup $(\mathrm{Eb})$, which received $13.5 \mathrm{mg} / \mathrm{kg}$ of sildenafil for a long time, showed that almost total affection of testicular tissue was apparent as compared to that of subgroup (Ea). In subgroup (Eb) the testicular tissues showed that most of the seminiferous tubules appeared depleted of most of the spermatogenic cells as there were large empty spaces in between germ cells that appeared detached and shrunken with pyknotic nuclei. The basement membrane was thin and irregular with few sperm flagella in the lumens of tubules. These findings were proved by PCNA-LI value that was significantly lower in subgroup (Eb) $(14.3 \pm 0.7)$ as compared to that of the control subgroups.

This could be explained by ${ }^{[29]}$ who reported that with increasing the dose of sildenafil citrate there were decrease of both spermatogenesis and spermiogenesis. $\mathrm{Also}^{[30]}$ reported that sildenafil provoked alterations in the epididymal epithelial lining in adult male rabbits, with partial arresting spermatogenesis and impairing the spermatic cells differentiation and maturation. Correspondingly ${ }^{[31]}$ studied chronic use of high doses of Phosphodiesterase-5 Inhibitors including (sildenafil and tadalafil) and Tramadol or sildenafil + tramadol combination at high doses, they reported that high doses of sildenafil, tadalafil, tramadol or sildenafil + tramadol caused significant degenerative changes in rat testis and epididymis, which negatively affects sperm characteristics with poor reversal following withdrawal of treatment.

Royal jelly has a protective effects on different tissues, in which they have anti-inflammatory, antioxidant, antihypercholesterolemia and hypoglycemic properties ${ }^{[32]}$. Moreover, royal jelly contained major proteins that were responsible for antioxidant activity ${ }^{[33]}$.

In the present work the rat's testicular sections from subgroup (Ta) revealed almost total improvement in germinal epithelium, with appearance of seminiferous tubules comparable to those of the control group with increase in sperm flagella in the lumens of the seminiferous tubules as compared to that of subgroup (Ea).Subgroup ( $\mathrm{Tb}$ ) showed a partial improvement in which some seminiferous tubules appeared with intact germinal epithelium and sperm flagella in their lumens as compared to that of subgroup (Eb). However, there were some seminiferous tubules showing germ cells with pale nuclei and few sperm flagella. These findings were proved by PCNA-LI values which revealed a significant increase in the PCNA-LI values of subgroups $\mathrm{Ta}$ and $\mathrm{Tb}(63.9 \pm 1.1$ and51.3 \pm 1.1 respectively) as compared to that of the experimental subgroups.

This result was agreed by ${ }^{[34]}$ in which it showed that oral administration of royal jelly at any level could be used 
beneficially to have earlier puberty age, improve semen quality and fertility of male rabbits. ${ }^{[35]}$ Concluded that supplementation of RJ in freezing extender can improve the cryosurvival rate and in vitro fertilizing capacity of buffalo bull sperm.

Moreover ${ }^{[36]}$ reported that daily administration of royal jelly caused a significant increase in sperm count, maturation, motility, and plasma testosterone levels. Moreover, it caused decreased DNA damage percentage which could be due to the fact that royal jelly mainly includes proteins, sugars, lipids, vitamins, and free amino acids. Also they concluded that RJ may be used in combination with Oxymetholone a synthetic androgen used for improve athletic ability and muscle mass. As RJ improves Oxymetholone induced oxidative stress and male infertility. Also ${ }^{[37]}$ added that royal jelly reduces reproductive toxicity of nicotine in mice by improving the testicular structure and sperm parameters.

\section{CONCLUSION}

Based on the results of the present study, it can be concluded thatlong-term daily use of sildenafil citrate produced histological changes in the testis and reduced the spermatogenesis with a significant decrease in sperm count and these side effects can be prevented partially or totally according to the dose of sildenafil citrate used by using royal jelly.

\section{ACKNOWLEDGEMENTS}

Our deep gratitude and appreciation to anatomy department Faculty of Medicine, Benha University for their help and support.

\section{CONFLICT OF INTEREST}

Authors declare that there is no conflict of interest

\section{REFERENCE}

1. Aldo E Calogero, Giovanni Burgio, Rosita A Condorelli, Rossella Cannarella, Sandro La Vignera. Lower Urinary Tract Symptoms and Benign Prostatic Hyperplasia and erectile dysfunction, from physiology to clinical aspects, 2018 ; the aging male journal volume 21 issue 4 Pages 261-271

2. Özgür BC, Telli O, Yuceturk CN, Sarici H, Ozer E, Surer H, Kilınc AS, Hucumenoglu S, Eroglu M. The effect of sildenafil and udenafil on testicular damage following ischemia-reperfusion injury in rats.2014; J Urol. 192(4):1272-7. doi: 10.1016/j.juro.

3. Spitzer M1, Bhasin S, Travison TG, Davda MN, Stroh H, Basaria S. Sildenafil increases serum testosterone levels by a direct action on the testes. 2013; Andrology. 1(6): 913-8. doi: 10.1111/j.20472927.2013.00131.x. Epub 2013 Sep 18.
4. Steve Tardif, Oladipo A Madamidola, Sean G Brown, Lorna Frame, Linda Lefièvre, Paul G Wyatt, Christopher L.R Barratt, Sarah J, Martins Da Silva. Clinically relevant enhancement of human sperm motility using compounds with reported phosphodiesterase inhibitor activity.2014; Hum Reprod. 10; 29(10): 2123-2135. PMID: 25124668

5. Ezz Eldin E Abdalla, Zienab M Gebaly, AbdElghany A Moustafa, Ibrahim M Amr. Evaluation the effect of sildenafil citrate (sc or Viagra) on senile albino rat testis (histological and biochemical study) 2012; The Egyptian Journal of Hospital Medicine Vol. 49; 911-932.

6. Yuan Yuan Shi, Xiao Bo Wu, Zachary Y. Huang, Zi Long Wang, Wei Yu Yan, Zhi Jiang Zeng. Epigenetic Modification of Gene Expression in Honey Bees by Heterospecific Gland Secretions 2012; https:// doi.org/10.1371/ journal.pone.0043727

7. Fratini F1, Cilia G2, Mancini S2, Felicioli A3. Royal Jelly: An ancient remedy with remarkable antibacterial properties. 2016; Microbiol Res.192:130-141. doi: 10.1016/j. micres.2016.06.007.

8. Khazaei M, Ansarian A, Ghanbari E. New Findings on Biological Actions and Clinical Applications of Royal Jelly: A Review. 2018; J Diet Suppl. 3;15(5):757-775. doi: 10.1080/19390211.2017.1363843.

9. Karaca T, Demirtaş S, Karaboğa İ, Ayvazz S. Protective effects of royal jelly against testicular damage in streptozotocin-induced diabetic rats. 2015; Turk J Med Sci.45(1):27-32.

10. Paget GE, Barnes JM: Evaluation of drug activities. In Pharmacometrics. Laurence DR, Bacharach AL (eds), (1964) ; vol. 1: 332-381. Academic Press, New York.

11. James G McMurray, Robert A Feldman, Stephen M Auerbach, Herb De Riesthal, Neal Wilson. Long-term safety and effectiveness of sildenafil citrate in men with erectile dysfunction 2007; Ther Clin Risk Manag; 3(6): 975-981.

12. Faisal MohamedAbou Tarboush, Mohamed FathyAbdel Samad, Mokhlid HamedAl Meteri. Developmental toxicity of orally administered sildenafil citrate (Viagra) in SWR/J mice. 2011; Saudi Journal of Biological Sciences Volume 18, Issue 2, April 2011, Pages 135-139

13. Elham Ghanbari, Vahid Nejati, Mozafar Khazaei: Antioxidant and protective effects of Royal jelly on histopathological changes in testis of diabetic rats 2016; Int J ReprodBioMed Vol. 14. No. 8. pp: 519-526.

14. Michael L Eisenberg, Lata Murthy, Kathleen 
Hwang, Dolores J Lamb, Larry I Lipshultz Sperm counts and sperm sex ratio in male infertility patients 2012; Asian J Androl. 14(5): 683-686. Published online 2012 Jul 30. doi: 10.1038/aja.2012.58

15. Lucio RA, Tlachi-López JL, Eguibar JR, Ågmo A. Sperm count and sperm motility decrease in old rats. Physiol Behav2013.; 17;110-111:73-9. doi: 10.1016/j.physbeh.2012;12.015. Epub 2013 Jan 4.

16. Ibtisam KhalafAbd Ali, Khalid KamilKadhim, Anam Rashid Al-salihi. Histological and Immunohistochemical Comparison of Mature Rat Testes with Glycerol, Propanediol and Dimethylsulphoxide as Cryoprotectants Advances in Animal and Veterinary Sciences. 2016 ; Volume 4 Issue 1 Page 35

17. Menna M. Abdel-Dayem. Histological and Immunohistochemical Changes in the Adult Rat Testes after Left Experimental Varicocele and Possible Protective Effects of Resveratrol, 2009; Egypt. J. Histol. Vol. 32, No. 1,: 81 - 90.

18. Michael Robert D'Andrea, Lawrence D, Robert G Nagele, Bruce Damiano. PCNA indexing as preclinical immunohistochemical biomarker for testicular toxicity,2008;Biotechnic and Histochemistry83(5):211-20DOI: $10.1080 / 10520290802521804$

19. Nilgun Gurbuz, ArifKol, TumayIpekci, ErhanAtes, AsliBaykal, MustafaF Usta. Chronic administration of sildenafil improves erectile function in a rat model of chronic renal failure, 2015; Asian J Androl. Sep-Oct; 17(5): 797-801 PMID: 25652632 doi: [10.4103/1008-682X.146973]

20. Ahmadnia H, Sharifi N, Alizadeh S, Roohani Z, Kamalati A, Marjan SS Wonderful Effects of Royal Jelly on Treatment of Male- Factor Related Infertility. 2015; Austin J Reprod Med Infertil.; 2(6): 1031.

21. Hassan A A. Effect of royal jelly on sexual efficiency in adult male rats.2009; Proceedings of the 5th Scientific Conference, Department of physiology, College of Veterinary Medicine, University of Mosul, Iraq 155.

22. El-Hanoun A M, Elkomy A E, Fares W A, Shahien E H. Impact of royaljelly to improve reproductive performance of male rabbits under hot summer conditions 2014; UniversitatPolitècnica de València World Rabbit Sci, 22: 241-248

23. Dimitriadis F, Asian J, Androl. Effect of phosphodiestrase -5 inhibitors on sperm parameters and fertilizing capacity 2008; 10(1) :115-133. PMID:18087651.

24. Maria Inês Sousa,Sandra Amaral,Renata Santos Tavares,Carla Paiva, JoãoRamalho-Santos Concentration-dependent Sildenafil citrate (Viagra) effects on ROS production, energy status, and human sperm function 2014; J systems biology in reproductive medicine, volume 60 issu 2 Pages 72-79

25. Giorgio Pomara, Girolamo Morelli, Domenico Canale, Paolo Turchi, Carolina Caglieresi, Cecilia Moschini, Giovanni Liguori, Cesare Selli, Enrico Macchia, Enio Martino, Francesco Francesca .Alterations in sperm motility after acute oral administration of sildenafil or tadalafil in young, 2007; infertile menVolume 88, Issue 4, Pages 860-865

26. Ali ST and Rakkah NI. Neurophysiological role of sildenafil citrate (Viagra) on seminal parameters in diabetic males with and without neuropathy. 2007; Pak J Pharm Sci. 20:36-42

27. Al-Fartosi KG. Effect of Long Term Adminstration of Sildenafil Citrate (Viagra) on Some Sperm Characteristic and Tests Architecture of Male Rats.2009; Bas. J. Vet. Res; 8:91-103.

28. Ataman JE andSakpa CL. Histo-morphometric effects of sildenafil citrate on the testis of normoglycaemic and hyperglycaemic adult wister rats. 2018; European Journal of Biology and Medical Science Research Vol.6, No.2, pp.6-20

29. Tuorkey M and Abdul Aziz K. Effects of sex enhancing drugs on different organs in male Swiss Albino Mice 2012; Values of Safety, Scientific Reports, 1:133-145.

30. Bashir M. Jarrar. Histological Alterations in the Rabbit Epididymis Induced by Sildenafil 2014; Overdosing British Journal of Medicine and Medical Research 4(5):1204-1216, 2014.

31. Victor U. Nna, Augustine L. Udefa, Emmanuel O. Ofutet, Eme E. Osim. Testicular and Epididymal Histology of Rats Chronically Administered High Doses of Phosphodiesterase-5 Inhibitors and Tramadol. 2017; Niger. J. Physiol. Sci. 32 55-61

32. Chiu HF, Chen BK, Lu YY, Han YC, Shen YC, Venkatakrishnan K, Golovinskaia O, Wang CK. Hypocholesterolemic efficacy of royal jelly in healthy mild hypercholesterolemic adults.2017; Pharm Biol. ;55(1):497-502.

33. VisweswaraRao Pasupuleti, Lakhsmi Sammugam, 
Nagesvari Ramesh, Siew Hua Gan Honey, Propolis, and Royal Jelly: A Comprehensive Review of Their Biological Actions and Health Benefits 2017; Oxidative MedicineandCellularLongevity Article ID 1259510, 21 pages https://doi. org/10.1155/2017/1259510

34. Khadr A H, Abdou A, El-Sherbiny A M. Age of puberty and fertility of male new zealand white rabbits orally administered with royal jelly or/ and bee honey 2015; J. Animal and Poultry Prod., Mansoura Univ., Vol.6 (4): 201 - 217. Dept., Faculty Agric., Ain Shams University, Cairo, Egypt.

35. Qaisar Shahzad, Muhammad Usman Mehmood, Hamayun Khan, Asmaul Husna, Saima Qadeer, Asima Azam, Zahid Naseer, Ejaz Ahmad,
Muhammad Safdar, Mushtaq Ahmad Royal jelly supplementation in semen extender enhances postthaw quality and fertility of Nili-Ravi buffalo bull sperm . April 2016Volume 167, Pages 83-88 DOI: https://doi.org/10.1016/j.anireprosci.2016.02.010

36. Ensieh Zahmatkesh, GholamrezaNajafi, VahidNejati, Reza Heidari. Protective effect of royal jelly on the sperm parameters and testosterone level and lipid peroxidation in adult mice treated with oxymetholone Avicenna 2014; J Phytomed. 4(1): 43-52 PMID: 25050300.

37. Azad A, Najati V, Shalizarjalali A, NajafiGh, RahmaniF. The Protective Effect of Royal Jelly on Testicular Tissue and Sperm Parameters in Adult Mice Treated with Nicotine. 2018; Journal of Babol University of Medical Sciences 20(3) 


$$
\text { الملخص العربى }
$$

\section{التأثير السمى للسيلاينافيل سترات على خصية الجرذان البيضاء البالغه و الدور}

\section{الوقائى الممكن من الرويال جيل (دراسه نسيجيه ومناعه كميائيه)}

$$
\text { قنان ابراهيم الكرداسى و على محمد على محمد التشريح والاجنه ــ كلية الطب ـ جامعة بنها }
$$

المقدمه: يعتبر ظهور مضادات الفسفوداى استير ات أداه ساحره فى علاج مشاكل الانتصاب ولكن ممكن ان تؤدى الى مشاكل ضاره عند استخدامها بجر عات عاليه ولمده طويله. الهـف من هذه الاراسه: تقييم تأثير السيلدينافيل سترات على خصية الجرذان البيضاء البالغه و الوقايه من هذا التنأثير بو اسطه استخدام الرويال جيل. طرق البحث: أجريت هذه الدر اسه على خمسه وثلاثون جرذ ذكر ابيض بالغ وقسمت الى مجمو عه ضابطه ومجمو عه

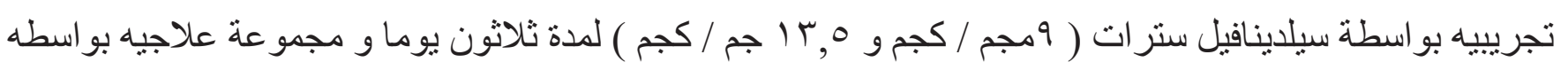
رويال جيل ( • ، ( مجم /كجم ) لمدة ثلاثون يوما بعد انهاء جر عة السيلدينافيل ستر ات لمدة ثلاثون يوما سابقه ثم تقيم

$$
\text { عدد الحيو انات المنويه ودر اسه النسيجيه و النسيجيه الكيميائيه. }
$$
النتائج :استخدام مادة السيلدينافيل سترات له نأثثر ضار على الخصيه في الجرذان البيضهاء البالغه من حيث عدد الحيو انات المنويه و التركيب الخلوى و الكميائى للخلايا ومع استخدام مادة الرويال جيل اظهرت تحسنا فى التركيب

$$
\text { النسيجى و اعداد الحيو انات المنويه. }
$$

الخلاصه: استخدام السيلدينافيل ستر ات لمده طويله له تأثثر ضار على الخصيه و انتاج الحيوانات المنويه وهذا التأثير يتحسن بأستخدام مادة الرويال جيل. 